\title{
IMPLEMENTASI TA'WIDH PADA PEMBIAYAAN KPR STUDI KASUS DI BTN SYARIAH CABANG JOMBANG
}

\author{
Imam Azizuddin dan Saeful Bahri \\ UIN Maulana Malik Ibrahim Malang \\ Email: imamazizuddin@uin-malang.ac.iddan hanyasaeful@gmail.com
}

\begin{abstract}
KPR BTN iB financing in BTN Syariah Jombang using murobahah and istishna' agreements in installments. This allows customers to experience late payment of installments, this results in BTN Syariah charging ta'widh to debtors. This study aims find: Implementation of Ta'widh on KPR financing in BTN Syariah Jombang and Review of fatwa DSN-MUI Number 43/DSNMUI/VIII/2004 in the procedure of determining ta'widh. The method used in this study is to take data according the facts with the method of Observation, Interview, and Library Study. The results of this study show that BTN Syariah is different from the fatwa DSN on the point of special provisions paragraph 3 , in the contract should not list the value of the amount of Ta'widh. However, in practice, BTN has determined the amount of ta'widh, which is each Rp.100.000,- from the installment arrears set ta'widh amounting to Rp.67,- multiplied by the number of days of arrears.
\end{abstract}

Keywords: Ta'widh, KPR Financing, Murobahah, and Istishna'.

\begin{abstract}
Abstrak
Pembiayaan KPR BTN iB yang ada di BTN Syariah Jombang memakai akad murobahah dan istishna' dengan cara diangsur. Hal tersebut memungkinkan nasabah mengalami telat bayar angsuran, ini mengakibatkan BTN Syariah membebankan ta'widh pada debitur. Penelitian ini bertujuan untuk mengetahui: Implementasi Ta'widh pada pembiayaan KPR di BTN Syariah cabang Jombang dan Peninjauan fatwa DSN-MUI Nomor 43/DSNMUI/VIII/2004 dalam prosedur penentuan ta'widh. Metode yang digunakan dalam penelitian ini yaitu mengambil data sesuai fakta yang ada dengan metode Observasi, Wawancara dan Studi Pustaka. Hasil dari penelitian ini menunjukan bahwa BTN Syariah berbeda dengan fatwa DSN pada poin ketentuan khusus ayat 3, dalam akad tidak boleh mencantumpakn nilai besarnya Ta'widh, akan tetapi pada praktiknya pihak BTN sudah menentukan besaran ta'widh yakni tiap-tiap Rp.100.000,- dari tunggakan angsuran ditetapkan ta'widh sebesar Rp.67,- dikalikan jumlah hari tunggakan tersebut.
\end{abstract}

Kata Kunci: Ta'widh, Pembiayaan KPR, Murobahah, dan Istishna'. 


\section{PENDAHULUAN}

Setelah pemerintah menetapkan bank muamalat pada tahun 1992 sebagai perbankan penggerak dan pelopor berkembangnya perbankan dengan prinsip Syariah di Indonesia, mulailah bermunculan dan lahir berbagai Lembaga yang mengikuti untuk menjalankan transaksi keuangan berprinsip Syariah. Mula-mula dari hanya yang menerima tabungan dengan prinsip Syariah kemudian berkembang pada pembiayaan Syariah, sampai pada bergerak pada usaha Syariah. BTN merupakan salah satu bank pemerintah yang juga ikut melakukan transaksi keuangan Syariah diberbagai produk keuangan. Sekitar tahun 1994 melalui Bank Indonesia telah memutuskan PT. Bank Tabungan Negara (Persero) sudah bisa menjalankan fungsi perbankan sebagai bank devisa. Selain keputusan dari BI, ada juga keputusan dari Menteri BUMN sebagi wakil pemerintah setelah mendapatkan kajian dari konsultan independent price water house coopers untuk memberikan kepada bank BTN sebagai bank umum yang berfokus pada pinjaman dengan tanpa subsidi untuk perumahan (Bank Tabungan Negara, 2005).

Proses pelayanan yang diterapkan pada BTN Syariah mulai awal pembukaan yakni menerapkan dual Banking System. Penerapan Unit usaha Syariah yang dijalankan BTN ini bisa dikatakan berpotensi untuk berkembang sebagai unit layanan bisnis KPR dengan prinsip Syariah. Kondisi seperti ini sudahlah sangat tepat dengan mengacu pada peraturan dari Menteri perumahan rakyat tentang pengadaaan perumahan dan Permukiman melalui support yang besar daripada penyedia subsidi rumah melalui program KPR/KPRS bersubsidi (Bank Tabungan Negara, 2005).

BTN Syariah cabang Jombang Sebagian dari beberapa kantor cabang BTN yang juga menerapkan penyaluran dengan sistem dana diantaranya Kredit pemilikan rumah Syariah (KPRS) yang sudah sesuai dengan kajian Syariah. KPR syariah adalah proses pemilikan rumah dengan menggunakan pembiayaan secara Syariah dengan berbagai macam pilihan akad yang diterapkan, yakni penjualan dengan tegas denngan mendapat keuntungan (murobahah), sistem penjualan dengan termin dan kontruksi (istishna'), sewa diawal dan akan menjadi kepemilikan diakhirnya (ijarah muntahiyah bit tamlik), Kerjasama dalam sewa (musyarokah mutanaqishah) (Ifham, 2017).

Produk KPR di BTN Syariah Cabang Jombang diantaranya KPR BTN Bersubsidi iB dan KPR BTN Platinum dengan menggunakan akad Murobahah (jual beli) dan KPR BTN Indent iB dengan menggunakan akad Istishna' (pesanan). Dengan adanya produk Pembiayaan KPR Tidak salah jika banyak orang yang memilih untuk mendapatkan rumah dengan cara kredit, dimana seseorang akan mendapatkan rumah yang dijamin keamanannya, dengan menggunakan layanan yang sudah pasti dan berbagai keuntungan yang akan didapatkan, seperti kepastian kepemilikan, uang muka ringan, legalitas kepemilikan, dan sarana berinvestasi.

Seiring dengan perkembangan perbankan syariah, sekarang banyak orang yang memilih pembiayaan syariah untuk kepemilikan rumahnya (Nufus, 2006). Sebelum mengajukan Kredit Pemilikan Rumah (KPR), calon debitur harus mengetahui mengenai syarat dan ketentuan kemudian melengkapi berbagai macam dokumen. Setelah calon nasabah melengkapi persyaratan tersebut kemudian diberikan ke pihak bank, Proses permohonan pembiayaan Kredit Pemilikan Rumah (KPR) dimulai sejak calon debitur diterima oleh BTN Syariah cabang Jombang, dengan menyerahkan beragam persyaratan yang harus dipenuhi sampai pada melangsungkan perjanjian kontrak setelah semua dokumen dinyatakan benar dan disetujui dan selanjutnya pihak debitur tinggal melangsungkan kewajibanya membayar tiap bulan dengan besaran yang sudah disepakati waktu perjanjian KPR. 
Resiko yang pasti muncul dengan model angsuran adalah timbulnya wanprestasi (lalai memenuhi kewajiban membayar) dari pihak nasabah (debitur), terlambat membayar angsuran KPR rumah dapat dipengaruhi oleh faktor internal maupun eksternal dari masing-masing debitur. Keterlambatan membayar dari pihak debitur ini sudah diantasipasi pihak bank dari awal pada waktu melangsungkan perjanjian kontrak dan sanksi harus diterima oleh debitur, seperti membayar denda keterlambatan sampai pada yang terparah rumah KPR diminta oleh pihak bank untuk diproses jual melalui lelang. Pada dasarnya pemberlakuan denda itu memang boleh sesuai dengan fatwa DSN No: 43/DSNMUI/VIII/2004 tentang ganti rugi ( $t a$ 'widh).

Pada BTN Syariah cabang Jombang, mengaplikasikan sanksi berupa ta'widh (ganti rugi) diterapkan kepada nasabah yang memang tidak bisa menunaikan kewajibannya membayar angsuran baik disebabkan karena teledor atau benar-benar disengaja, maka setelah tanggungan tersebut melewati batas akhir waktu dalam kontrak perjanjian yang sudah dibuat diawal, debitur tersebut bisa dikenakan sanksi ganti rugi (ta'widh).

Dalam kasus yang terjadi di BTN Syariah cabang Jombang yakni pada saat penandatanganan akad Pembiayaan KPR BTN iB antara pihak Bank dan nasabah nominal denda bagi nasabah yeng telat membayar disebutkan oleh pihak bank, selain itu juga ada keluhan dari nasabah yang dikenakan denda karena telat membayar angsuran.

Untuk itu maka peneliti ingin mendalami dan mengkaji lebih dalam mengenai pertama, bagaimana implementasi Ta'widh (ganti rugi) pada pembayaran KPR BTN iB di BTN Syariah cabang Jombang. Kedua, bagaimana Peninjauan fatwa DSNMUI Nomor 43/DSNMUI/VIII/2004 tentang Ta'widh dalam prosedur penentuan ganti rugi (ta'widh) pada KPR BTN iB di BTN Syariah cabang Jombang.
Dengan demikian tujuan dari penilitian ini adalah untuk mengetahui gambaran penerapan ta' widh yang dilakukan BTN iB dalam pembayaran KPR serta mengetahui penerapan fatwa DSN_MUI dalam prosedur penentuan ganti rugi pada pembiayaan KPR.

\section{LITERATURE REVIEW}

Penelitian yang sudah pernah dilakukan yang memiliki kesamaan tema masalah ganti rugi dengan maksud untuk mendukung dan tidak ada pengulangan dalam penelitian yang sama, diantaranya pertama, penelitian oleh Umul Khair (2017) dengan judul "Analisis Yuridis Perjanjian Pembiayaan Konsumen Dan Akibat Hukum Jika Terjadi Wanprestasi Dalam Perjanjian Pembiayaan Konsumen di Indonesia", dengan pendekatan yuridis normatif. Penelitian ini bertujuan untuk mengetahui penerapan dan akibat hukum perjanjian pembiayaan konsumen di Indonesia. Berdasarkan hasil penelitian tersebut menerangkan bahwa adannya hukuman akibat terjadi kelalaian debitur (wanprestasi), secara otomatis perjanjian tersebut dinyatakan batal demi hukum meskipun tanpa dimintakan pembatalan (Khair, 2017).

Kedua, penelitian oleh Teuku Arie Azhari dan Burhanudin Harahap (2018) dengan judul "Analisis Penerapan Biaya Atas Keterlambatan Pembayaran Atau Denda Dalam Pembiayaan Al Murabahah Pada Perbankan Syariah", dengan menggunakan metode yuridis normatif. Tujuan penelitian ini adalah berupaya mengetahui penerapan biaya atas keterlambatan atau denda pada pembiayaan al murabahah pada perbankan Syariah. Dari penelitian tersebut memperoleh hasil bahwa implementasi denda atas terjadinya tunggakan angsuran dalam pembiayaan al murabahah pada bank Syariah tidak diperkenankan, karena dapat diasumsikan dengan adanya ganti rugi tersebut nilai jual atas barang menjadi bertambah (Azhari, 2018).

Ketiga, hasil penelitian bentuk skripsi oleh Nika Rahmawati (2019) dengan judul 
“praktek pelaksanaan ganti rugi (ta'widh) di pegadaian syariah kendal permai (perspektif DSN-MUI no. 46/DSNMUI/VIII/2004 tentang ganti rugi (ta'widh)", dengan menggunakan metode deskriptif. Tujuan dalam penelitian tersebut adalah untuk mengetahui praktik serta mengetahui tinjauan fatwa DSN-MUI tentang Ta'widh melalui akad Rahn pada produk amanah di pegadaian Syariah. Hasil dari penelitian tersebut menerangkan sistem ganti rugi pada produk Amanah diterapkan kepada nasabah yang lalai dalam pembayaran angsuran tapi dengan menginfokan terlebih dahulu kepda nasabah bahwa sudah jatuh tempo tidak langsung melakukan penyitaan terhadap barang (Rahmawati, 2019).

Penelitian yang peneliti jalankan ini berbeda dengan penelitian yang sudah ada yaitu dalam hal penerapan fatwa DNS-MUI pada ketentuan khusus ayat 3 dijelaskan, dalam akad tidak boleh mencantumpakn nilai besarnya Ta'widh

\section{METODE PENELITIAN}

Penelitian ini adalah penelitian kualitatif yaitu penelitian dengan data yang diperoleh dari penelitian langsung (Soekamto, 1996). Sumber datanya didapat dari kenyataan yang ada dan terjadi di BTN Syariah cabang Jombang.

Dalam penelitian ini penulis menggunakan metode analisi isi (content analysis) yakni pembahasan yang mendalam terhadap isi suatu informasi tertulis pada Fatwa DSN No. 43/DSN-MUI/VIII/2004 tentang Ganti Rugi (ta'widh).

Untuk analisa data terhadap penentuan Ta'widh maka Penulis akan melakukan evaluasi sehingga apabila masih ada kekurangan peneliti dapat memperbaiki kembali. Atau jika masih terdapat informasi yang mengganjal, peneliti akan menggali informasi kembali kepada pihak BTN Syariah cabang Jombang. Setelah semua terselesaikan dan permasalahan telah terjawab, penulis akan menyimpulkan hasil dari analisa penelitian yang dilaksanakan di BTN Syariah cabang Jombang.

\section{KONSEP DASAR}

\section{Penjelasan Ta'widh}

Ta'widh didefinisikan adalah biaya yang harus dikeluarkan oleh debitur dikenakan kelalaian atau terlambat dalam melakukan kewajiban angsuran yang mengakibatkan bank mengalami kerugian. Kerugian disini karena dengan nyata ada biaya yang dialokasikan untuk penagihan kepada debitur dalam bentuk penagihan langsung (biaya transportasi), biaya telepon dan lain-lain (Ifham, 2017).

Menurut Bagya dalam bukunya menerangkan bahwa Ta'widh adalah sebagai wujud imbalan, sanksi yang dikeluarkan karena adanya ketidaksesuaian akad. Ketidaksesuaian akad ini adalah ada pihak yang dengan direncana tidak menepati kewajibanya yang sudah disepakati pada waktu kontrak yang mengakibatkan munculnya kerugian yang dialamai oleh pihak yang lain (Prabowo, 2012).

Jikalau ada indikasi dari pihak debitur dengan sengaja melakukan hal yang sudah tidak sesuai dengan kontrak dan membuat pihak bank mengalami kerugian, maka pihak yang dirugikan (kreditur) bisa memaksa debitur untuk membayar ganti rugi sesuai yang sudah disetujui waktu kontrak awal. Dewan Syari'ah telah mengadopsi konsep denda terhadap mereka yang tidak melunasi hutang pada tepat waktu khususnya jika nasabah mampu melunasi.

\section{Dasar Hukum Ta'widh}

Surat al-Baqarah ayat 194 :

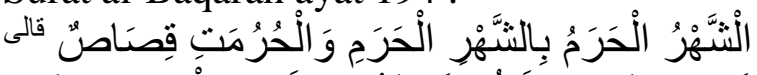

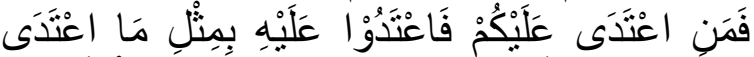

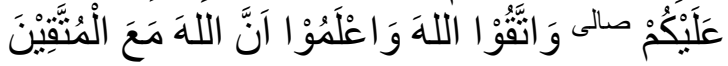

Artinya: Bulan haram dengan bulan haram, dan (terhadap) sesuatu yang dihormati berlaku (hukum) qisas. maka barang siapa melakukan aniaya (kerugian) kepadamu, balaslah ia, seimbang dengan kerugian yang telah ia timpakan kepadamu. Bertakwalah kepada Allah dan ketahuilah, bahwa Allah 
beserta orang-orang yang bertakwa (Departemen Agama R. I., 2005).

\section{Syarat Sah Ta'widh}

System ganti rugi (ta'widh) mempunyai beberapa ketentuan untuk bisa dijalankan secara Syariah, pendapat Wahbah al-Zuhaily secara umum ketentuan ta'widh dalam lingkup: mengganti kerugian dengan benda, seperti membenahi pintu yang dirusak dikembalikan menjadi utuh lagi, seperti halnya mengganti barang yang dipecahkan kepada bentuk yang utuh. Jikalau hal tersebut berat untuk dipenuhi, maka harus mengganti dengan yang sejenis atau dengan uang. Namun apabila keuntungan itu tidak bisa didapat dan kerugian yang belum pasti diwaktu mendatang atau kerugian non benda, maka dari berbagai pendapat dalam ketentuan fiqih hal seperti itu tidak bisa dimintakan ta'widh. Dalam syariat yang bisa diganti (ta'widh) hanya pada objek harta yang wujud dan nyata serta mempunyai nilai (Prabowo, 2012)

\section{Tujuan Ta'widh}

Pembelakuan Ta'widh oleh BTN Syariah cabang Jombang bertujuan untuk agar semua debitur yang melakukan akad pembiayaan KPR tidak mengalami keterlambatan dalam memenuhi kewajibanya sesuai kontrak yang sudah dijanjikan. Denda ini diberlakukan agar kedua belah pihak baik nasabah maupun pihak bank saling menguntukan dan samasama memperoleh mannfaat. Disisi lain model ganti rugi, akan memberikan dampak jera pada nasabah untuk tidak melakukan Tindakan yang sama. Pihak bank juga berharap penerapan ta'widh ini hanya sebagai peringatan kepada nasabah, dengan harapan semua nasabah tidak sampai lalai dalam kewajibanya, namun apabila terjadi kelalaian proses ganti rugi juga bisa berjalan lancar agar antara nasabah dan pihak bank selalu terjalin komunikasi yang lebih baik.

\section{Pembiayaan KPR}

Pembiayaan KPR untuk tujuan memenuhi kebutuhan pokok itu masuk dalam jenis kredit komsumtif, dimana kredit ini diperuntukan untuk pembelian berbagai macam barang dan jasa untuk memenuhi kepuasan langsung terhadap kebutuhan konsumen. Berarti KPR bisa juga dijabarkan sebagai kredit yang diminta oleh dibitur kepada pihak bank untuk berbagai variasi kebutuhan missal untuk mendirikan, renovasi, beli atau memperluas lahan dengan cara bayar angsuran tiap bulan sampai waktu tertentu sesuai dengan perjanjian dari kedua belah pihak.

BTN Syariah cabang Jombang juga menyediakan layanan dana khusus KPRS sesuai dengan prinsip-prinsip Syariah Islam. Produk-produk KPR iB yang disediakan oleh BTN Syariah cabang Jombang diantaranya KPR BTN Bersubsidi iB dan KPR BTN Platinum dengan menggunakan akad Murabahah (jual beli) dan KPR BTN Indent iB dengan menggunakan akad Istishna' (pesanan).

Akad yang digunakan BTN Syariah cabang Jombang, yaitu pertama, akad Murobahah adalah salah satu bentuk jual beli dalam Syariah Islam dimana penjual memberitahukan biaya perolehan barang, mencakup pembelian barang serta biaya lainya yang dihabiskan untuk pemerolehan yang dimaksud, dan tingkat laba (margin) yang diharapkan (Ascaraya, 2007).

Jual beli al Murabahah adalah model transaksi barang dengan menggunakan harga awal dengan imbalan laba yang sudah disepakati bersama (Antonia, 2017). Dalam jual beli al Murobahah, pihak penjual punya kewajiban menginfokan harga barang yang dibeli serta menentukan margin sebagai tambahannya. Margin adalah perbedaan nilai dari harga jual dikurangi harga awal yang merupakan sebagai penghasilan bank (Dewi, 2007).

Kedua, Istishna' menurut beberapa sumber : Dalam Fatwa DSN-MUI No. 06/DSN-MUI//IV/2000 tentang Istishna' dijabarkan bahwa jual beli Istishna' merupakan bentuk jual beli dengan model pemesanan untuk pembuatan suatu barang tertentu sesuai dengan kriteria-kriteria 
tertentu yang sudah menjalin mufakat antara pembeli (mustashni') dan penjual (shani') (Dewan Syariah Nasional Majelis Ulama Indonesia (DSN-MUI), 2000).

Istishna' merupakan termasuk pembiayaan dalam proses jual beli dengan model anguran sebagaimana proses murobahah muajjal. Akan tetapi, tidak sama dengan jual beli murobahah yakni barang jualbeli diberikan diawal transaksi namun uanganya diserahkan dengan angsuran, dalam jual beli istishna' barang diberikan di belakang, meskipun uangnya juga samasama dibayar secara angsuran (Karim, 2004).

\section{Fatwa DSN-MUI No. 43}

Dalam Fatwa Dewan Syari'ah Nasional NO. 43/DSN-MUI/VIII/2004 tentang Ganti Rugi (Ta'widh) memutuskan menetapkan : Fatwa Tentang Ganti Rugi (Ta'widh) (Dewan Syariah Nasional Majelis Ulama Indonesia, 2004).

1. Pertama: Ketentuan Umum

a. Ganti rugi (ta'widh) hanya boleh dikenakan atas pihak yang dengan sengaja atau karena kelalaian melakukan sesuatu yang menyimpang dari ketentuan akad dan menimbulkan kerugian pada pihak lain.

b. Kerugian yang dapat dikenakan ta'widh sebagaimana dimaksud dalam ayat 1 adalah kerugian riil yang dapat diperhitungkan dengan jelas.

c. Kerugian riil sebagaimana dimaksud ayat 2 adalah biaya-biaya riil yg dikeluarkan dalam rangka penagihan hak yg seharusnya dibayarkan.

d. Besar ganti rugi (ta`widh) adalah sesuai dengan nilai kerugian riil (real loss) yang pasti dialami (fixed cost) dalam transaksi tersebut dan bukan kerugian yang diperkirakan akan terjadi (potential loss) karena adanya peluang yang hilang (opportunity loss atau al-furshah al-dha-i'ah)

e. Ganti rugi (ta`widh) hanya boleh dikenakan pada transaksi (akad) yang menimbulkan utang piutang (dain), seperti salam, istishna' serta murabahah dan ijarah.

Dalam akad Mudharabah dan Musyarakah, ganti rugi hanya boleh dikenakan oleh shahibul mal atau salah satu pihak dalam musyarakah apabila bagian keuntungannya sudah jelas tetapi tidak dibayarkan.

2. Kedua: Ketentuan Khusus

a. Ganti rugi yang diterima dalam transaksi di LKS dapat diakui sebagai hak (pendapatan) bagi pihak yang menerimanya

b. Jumlah ganti rugi besarnya harus tetap sesuai dengan kerugian riil dan tata cara pembayarannya tergantung kesepakatan para pihak.

c. Besarnya ganti rugi ini tidak boleh dicantumkan dalam akad

d. Pihak yang cedera janji bertanggung jawab atas biaya perkara dan biaya lainnya yang timbul akibat proses penyelesaian perkara

3. Ketiga: Penyelesaian Perselisihan

Jika salah satu pihak tidak menunaikan kewajibannya atau terjadi perselisihan di antara kedua belah pihak, maka penyelesaiaannya dilakukan melalui Badan Arbitrase Syari'ah setelah tidak tercapai kesepakatan melalui musyawaroh.

4. Keempat: Ketentuan Penutup

Fatwa ini berlaku sejak tanggal ditetapkan dengan ketentuan, jika di kemudian hari ternyata terdapat kekeliruan, akan diubah dan disempurnakan sebagaimana mestinya.

\section{PEMBAHASAN DAN DISKUSI}

Bank Tabungan Negara mulai didirikan termasuk slah satu bank yang berfokus pada pada penyediaan bangunan rumah untuk masyarakat umum dengan menggunakan layanan KPR (Kredit Pemilikan Rumah). Hal yang terpenting bisa beroperasinya pembiayaan KPR oleh bank yang menjalankan prinsip hukum Islam adalah akad yang dijalnkan antara pihak nasabah dan pihak bank. Bank Syariah yang 
menjalankan prinsip Syariah, akad merupakan hal yang penting untuk dilakukan karena memiliki Dalam bank syariah, akad yang dilakukan memiliki pengaruh dunia sampai akhirat karena akad yang dijalankan berprinsip Syariah Islam.

Pada surat perjanjian pembiayaan antara pihak BTN Syariah cabang Jombang dan nasabah terdapat perihal yang menjadi keharusan dan pembagian masing-masing pihak. Jadi antara nasabah dan bank tidak diperbolehkan menjalankan kegiatan yang bertentangan dengan surat kontrak tersebut. Ketika nasabah melakukan pelanggaran diluar ketentuan maka pihak bank boleh memberikan sanksi. Tindak pelanggran yang dilakukan nasabah diantaranya lalai atau sengaja tidak melakukan kewajiban angsuran sampai jatuh tempo yang sudah disepakati, maka nasabah diberikan sanksi berupa ganti rugi (ta'widh).

Berbagai macam tanggapan dari nasabah yang mendapat sanksi denda karena kelalaian dalam angsuran, ada yang menanggapi dengan komplain, ada juga yang mengajukan keringanan, mengajukan tambahan waktu pembayaran tanpa ada denda, ada juga yang mempertanyakan kenapa ada denda sampai meminta perincian denda serta diskon dari denda tersebut. Tujuan dari BTN Syariah cabang Jombang dalam memberlakukan ta'widh supaya para debitur bisa tertib dalam angsuran serta membikin insaf para debitur (nasabah) yang tidak tertib. Adapun sanksi dapat berupa denda sejumlah uang yang besarnya ditentukan pada saat akad ditandatangani.

BTN Syariah cabang Jombang menerapkan metode dalam pembiayaan KPR BTN iB menggunaka metode keterlambatan juga menerapkan aturan dalam pembayaran yakni Pembayaran secara auto debet yaitu pembayaran dengan langsung melakukan pemotongan saldo secara sistem pada jam 12 malam sesuai waktu angsuran. Tanggal pembayaran ini tidak bisa diubah, Jadi dengan model atutodebet bila terjadi kegagalan dalam debet otomatis, bisa mengakibatkan gagal bayar yang mengakibatkan nasabah dijatuhi sanksi denda.

Perhitungan Ta'widh di BTN Syariah cabang Jombang, setiap debitur yang lalai dalam melakukan angsuran pembayaran KPR BTN iB baik disengaja atau tidak, maka setelah lewat waktu tanggal bayar yang sudah dijanjikan dalam kontrak (akad), debitur (nasabah) dikenakan ganti rugi (ta'widh) dengan jumlah yang tetap (flat) yaitu tiap-tiap Rp. 100.000,- dari tunggakan angsuran ditetapkan denda ( $t a$ 'widh) sebesar Rp. 67,-- dikalikan berapa jumlah hari tunggakan tersebut.

\section{Analisis Fatwa DSN NO. 43/DSN- MUI/VIII/2004}

Tindakan bank agar tidak sampai mengalami kerugian yang diakibatkan oleh tindakan dari nasabah berupa kelalaian dalam melakukan kewajiban angsuran pembayaran dari waktu yang sudah ditentukan pada akad, maka BTN Syariah cabang Jombang menerapkan adanya ta'widh. Dalam pelaksanannya BTN Syariah cabang Jombang memberikan ta'widh yang jumlahnya bersifat tetap yaitu tiap-tiap Rp. 100.000,- dari tunggakan angsuran ditetapkan denda ( $t a$ 'widh) sebesar Rp. 67,- dikalikan berapa jumlah hari tunggakan tersebut. Pemberian Ta'widh tersebut sesuai dengan Fatwa DSN NO. 43/DSN-MUI/VIII/2004 Tentang Ta'widh (Ganti Rugi).

Pada ketentuan umum ayat 1 dijelaskan "Ganti rugi (ta'widh) baru bisa diterapkan terhadap pihak yang secara terencana atau lalai sudah melakukan Tindakan yang melanggar ketentuan akad dan mengakibatkan ada pihak yang dirugikan". Dalam ayat tersebut sudah jelas bahwa nasabah yang dikenakan denda hanya nasabah yang dengan sengaja atau lalai. Nasabah di BTN Syariah cabang Jombang yang terkena denda memiliki berbagai macam alasan yang tidak sama. Sebagian nasabah ada yang beralasan kenapa menunda pembayaran dikarenakan mengalami kebangkrutan dalam usaha, sebagian lagi nasabah ada yang beralasan dikarenakan 
masih mengalami musibah, dan ada juga yang dikarenakan akibat kesengajaan nasabah. Sesuai dengan Fatwa DSN MUI No 43 ayat 1 praktik denda di Bank Tabungan Negara KCPS Jombang sesuai dengan aturan yang ada. nasabah dianggap lalai karena sebelum jatuh tempo nasabah tidak mengkonfirmasi kepada bank. Karena tidak adanya kejelasan dari nasabah maka bank tetap harus memberi denda pada nasabah karena hal tersebut merupakan kelalaian dari nasabah.

Pada ketentuan umum ayat $2-4$ menjelaskan "pihak yang wajib mengganti kerugian yang dialami pihak dalam transaksi ditanggung oleh pihak yang benar-benar menimbulkan kerugian yang nominalnya harus sesuai dengan jumlah kerugian". Pada ayat tersebut sudah jelas bahwa ketika Nasabah melakukan keterlambatan pembayaran angsuran maka pihak BTN Syariah cabang Jombang perlu membuat kebijakan mengenai ta'widh sebagai bentuk sanksi yang harus diterimanya. Kemudian untuk penetapan besarnya ta'widh ditentukan pada besaran kerugian yang sudah dialamai pihak BTN Syariah cabang Jombang, yakni ada biaya yang memang benar-benar dikeluarkan pada saat penuntutan pembayaran seperti biaya telepon, surat, transportasi, dan biaya-biaya lain yang memang telah dikeluarkan oleh bank syariah. Pada praktiknya Pihak BTN Syariah cabang Jombang telah membuat kebijakan besar ta'widh yang harus dibayarkan oleh nasabah. BTN Syariah cabang Jombang menetapkan ta'widh yang dicantumkan dalam akad yakni tiap-tiap Rp. 100.000,- dari tunggakan angsuran ditetapkan denda ( $t a$ ' widh) sebesar Rp. 67,- dikalikan berapa jumlah hari tunggakan tersebut, dimana jumlah biaya tersebut sudah melalui proses hitung yang dikeluarkan oleh bagian tim collection bank BTN Syariah atas biaya yang muncul, seperti biaya telepon, surat, transportasi dan biaya lainya. Namun jumlah total tersebut belum kesemuanya dari total biaya yang di keluarkan pihak BTN Syariah cabang Jombang hal ini karena interaksi bisnis tidak sebatas lingkup individu saja tapi sudah sampai ranah publik bahkan antar Negara sehingga untuk mempermudah pelaksanaan bisnis pembayaran dan ta'widh menggunakan sistem yang secara otomatis akan mendebet rekening.

Pada ketentuan umum ayat 5 dijelaskan "Ganti rugi (ta'widh) hanya boleh dikenakan pada transaksi (akad) yang menimbulkan utang piutang (dain), seperti salam, istishna', serta murabahah dan ijarah". Sesuai dengan ayat tersebut yang menjelaskan transaksi (akad) yang memperbolehkan diadakannya ta'widh adalah akad yang menimbulkan utang piutang. BTN Syariah cabang Jombang menyediakan Pembiayaan KPR Syariah dengan akad murobahah dan istishna' yang pembayarannya dilakukan dengan cara diangsur. Hal tersebut memungkinkan nasabah telat membayar angsuran sehingga hutang yang harus dibayar sebelum jatuh tempo menjadi utang yang menjadikan BTN Syariah cabang Jombang menetapkan ganti rugi pada debitur (nasabah). Berarti praktik tersebut sudah sesuai dengan Fatwa DSN No 43/DSN-MUI/VIII/2004.

Pada ketentuan umum ayat 6 menjelaskan "ganti rugi nasabah yang melakukan akad Mudharabah dan Musyarokah", sementara pada BTN Syariah cabang Jombang di Pembiayaan KPR BTN iB tidak menggunakan akad Mudharabah dan Musyarokah. Akad ini digunakan pada produk lain di BTN Syariah cabang Jombang.

Pada ketetapan Khusus dari fatwa DSN 43 tersebut menjelaskan mengenai: 1) kompensasi yang masuk pada perundingan di LKS bisa diakui sebagai pendapatan untuk yang meneriman. Berdasarkan hal tersebut BTN Syariah cabang Jombang menerima pendapatan dari ganti rugi dan sudah menjadi hak milik bagi BTN Syariah cabang Jombang. 2) besaran kompensasi harus sama dengan besaran kerugian yang diderita, dan tatacara pembayarannya diserahkan pada kedua pihak sesuai kesepakatan. Telah ditetapkan berdasarkan perhitungan tim 
collection BTN Syariah mengenai jumlah biaya ta'widh yang dikenakan pada nasabah yakni tiap-tiap Rp. 100.000,- dari tunggakan angsuran ditetapkan denda ( $t a$ 'widh) sebesar Rp. 67,- dikalikan berapa jumlah hari tunggakan tersebut. Untuk pembayarnnya juga sesuai dengan prosedur yang telah ditetapkan oleh BTN Syariah. 3) nominal kompensasi tidak sah ditulis dalam kontrak. Dalam bagian ini mekanisme penetapan ta'widh di BTN Syariah cabang Jombang tidak sesuai karena mencantumkan besarnya ganti rugi. Padahal dalam Fatwa DSN-MUI No. 43/DSN-MUI/VIII/2004 tidak boleh mencantumkan besarnya ganti rugi.

\section{Penyelesaian Nasabah Bermasalah}

BTN Syariah cabang Jombang melakukan berbagai cara untuk menyelesaikan nasabah yang melakukan wanprestasi, di antaranya:

Menerapakan degan cara negosiasi terhadap nasabah wanprestasi, cara ini dipakai untuk menggali informasi atas masalah yang dihadapi nasabah. Negosiasi tersebut dijalankan dengan mendatangkan nasabah ke bank kemudian mengupas segala masalah yang menimpa nasabah, dengan demikian pihak bank segera mengetahui apa yang menjadi penyebab pembiayaan bermasalah, sehingga bank bisa memutuskan atau mengambil tindakan yang tepat dalam menyelesaikannya. Seperti kapan nasabah harus menyelesaikan pelunasan, seperti perpanjangan waktu serta nilai angsuran yang mungkin berubah. Akan tetapi, dalam praktiknya tidak berjalan lancar karena sebagaian dari nasabah tidak menyetujui bentuk kerjasama dalam penyelesaian masalah secara kekeluargaan. Ada juga dari nasabah secara nyata berniat tidak mau menemui pihak bank.

BTN Syariah cabang Jombang secara intens menagih nasabah dengan berbagai cara, seperti menelpon nasabah yang mempunyai tunggakan, memberikan teguran atau peringatan melalui surat kepada nasabah KPR BTN iB yang kurang tertib dalam angsuran. Surat teguran tersebut akan dilayangkan sebanyak tiga kali dengan sifat yang berbeda, mulai dari SP1 yang berisikan peringatan terhadap nasabah dengan sanksi hanya status kurang lancar dalam kredit serta dalam pengawasan. Setelah dilayangkan surat pertama masih tetap kurang ada respon dari debitur untuk melakukan angsuran, maka akan dikirimkan SP2 dengan penurunan status menjadi kredit yang diragukan. Apabila SP 2 tetap juga tidak dihiruakan oleh nasabah serta tidak punya niat baik untuk dating ke bank, maka nasabah anak menerima SP3 dengan status kredit macet.

\section{Eksekusi Pembiayaan}

Setelah debitur berstatus kredit macet maka pihak bank akan mengeksekusi pembiayaan yaitu dengan cara melakukan pengambil alihan hak milik jaminan dan menjualnya, karena debitur sudah tidak bisa diharapkan lagi dalam pembiayaan.

Mengenai masalah Penguasaan dan Penjualan barang jaminan dalam Surat Perjanjian akad Pembiayaan KPR BTN iB Pasal 17 tentang Penguasaan dan Penjualan (eksekusi) Rumah Jaminan dijelaskan : pada ayat (4) : "Hasil eksekusi dan atau penjualan Rumah jaminan tersebut dalam pasal ini, diprioritaskan untuk melunasi seluruh sisa Utang Nasabah kepada pihak Bank, termasuk semua biaya yang telah dikeluarkan Bank guna melaksanakan penjualan atau eksekusi Rumah jaminan dan apabila masih ada sisanya maka jumlah sisa akan dibayarkan kepada Nasabah". Dan pada ayat (5): "Apabila dari hasil penjualan atau eksekusi Rumah jaminan Pembiayaan sebagaimana tersebut pada ayat 4 jumlahnya belum mencukupi untuk melunasi seluruh Utang Nasabah kepada Bank, maka sesuai dengan ketentuan dan peraturan yang berlaku, Bank berhak untuk mengambil pelunasan atas sisa Utang tersebut dari penjualan harta lain milik Nasabah".

\section{KESIMPULAN}

Setelah penyusun meneliti dan menganalisa dapat ditarik kesimpulan, sebagai berikut pertama, praktik denda di BTN Syariah 
cabang Jombang dilakukan berdasarkan Fatwa DSN No. 43/SN-MUI/VIII/2004, denda tersebut dilaksanakan apabila pada tanggal yang sudah ditentukan dan disepakati nasabah tidak dapat membayar hutangnya maka nasabah tersebut akan dikenakan ta'widh sebesar tiap-tiap Rp. 100.000,- dari tunggakan angsuran ditetapkan denda (ta'widh) sebesar Rp. 67,- dikalikan berapa jumlah hari tunggakan tersebut.

Kedua, Praktik denda pada Pembiayaan KPR BTN iB di BTN Syariah cabang Jombang sebagian besar sudah sesuai dengan aturan Fatwa DSN No. 43/DSNMUI/VIII/2004 hanya saja pada ketentuan khusus ayat 3 dijelaskan "Besarnya ganti rugi tidak boleh dicantumkan dalam akad." sedangkan di BTN Syariah cabang Jombang jumlah nominal denda ditentukan dan dicantumkan dalam surat perjanjian hal ini karena untuk mempermudah pelaksanaan bisnis pembayaran dan ta'widh menggunakan sistem yang secara otomatis akan mendebet rekening.

\section{DAFTAR PUSTAKA}

Antonia, M. S. (2017). Bank Syariah dari teori ke praktik. Jakarta: Gema Insani. Ascaraya. (2007). Akad dan Produk Bank Syariah. PT. RajaGrafindo Persada.

Azhari, T. A. B. H. (2018). "Analisis Penerapan Biaya Atas Keterlambatan Pembayaran atau Denda dalam Pembiayaan al-Murabahah pada Perbankan Syariah". Jurnal Repertorium, 5(2), 188-203.

Bank Tabungan Negara. (2005). Laporan Tahunan.

Departemen Agama R. I. (2005). Al-Qur'an dan Terjemahnya. J-Art.

Dewan Syariah Nasional Majelis Ulama Indonesia. (2004). Fatwa Dewan Syari'ah Nasional No. 43/DSNMUI/VIII/2004 Tentang Ganti Rugi (Ta'widh). 43, 6.

Dewan Syariah Nasional Majelis Ulama Indonesia (DSN-MUI). (2000). Fatwa Dewan Syari'ah Nasional No:
06/DSN-MUI/IV/2000 Tentang JUAL BELI ISTISHNA'.

Dewi, G. (2007). Aspek-aspek Hukum dalam Perbankan dan Perasuransian Syariah di Indonesia. Jakarta: Kencana Prenada Media Group.

Ifham, A. (2017). Ini Lho KPR Syariah! Jakarta: Gramedia Pustaka Utama.

Karim, A. A. (2004). Bank Islam Analisis Fiqih dan keuangan (V). Bandung: PT. RajaGrafindo Persada.

Khair, U. (2017). Analisis Yuridis Perjanjian Pembiayaan Konsumen Dan Akibat Hukum Jika Terjadi Wanprestasi Dalam Perjanjian Pembiayaan Konsumen Di Indonesia. JCH (Jurnal Cendekia Hukum), 3(1), 32. https://doi.org/10.33760/jch.v3i1.7

Nufus, H. (2006). Lebih Untung dengan KPR Syariah. Sharia Bssines Modal, 11.

Prabowo, B. A. (2012). Aspek Hukum Pembiayaan Murobahah Pada Perbankan Syariah. Jakarta: UII Press.

Rahmawati, N. (2019). Praktek Pelaksanaan Ganti Rugi (Ta'widh) di Pegadaian Syariah Kendal Permai (Perspektif DSN-MUI No. 46/DSNMUI/VIII/2004 Tentang Ganti Rugi (Ta'widh))". In UIN Walisongo (Vol. 4, Issue 1). UIN Walisongo.

Soekamto, S. (1996). Pengantar Penelitian Hukum. Jakarta: UI Press. 